
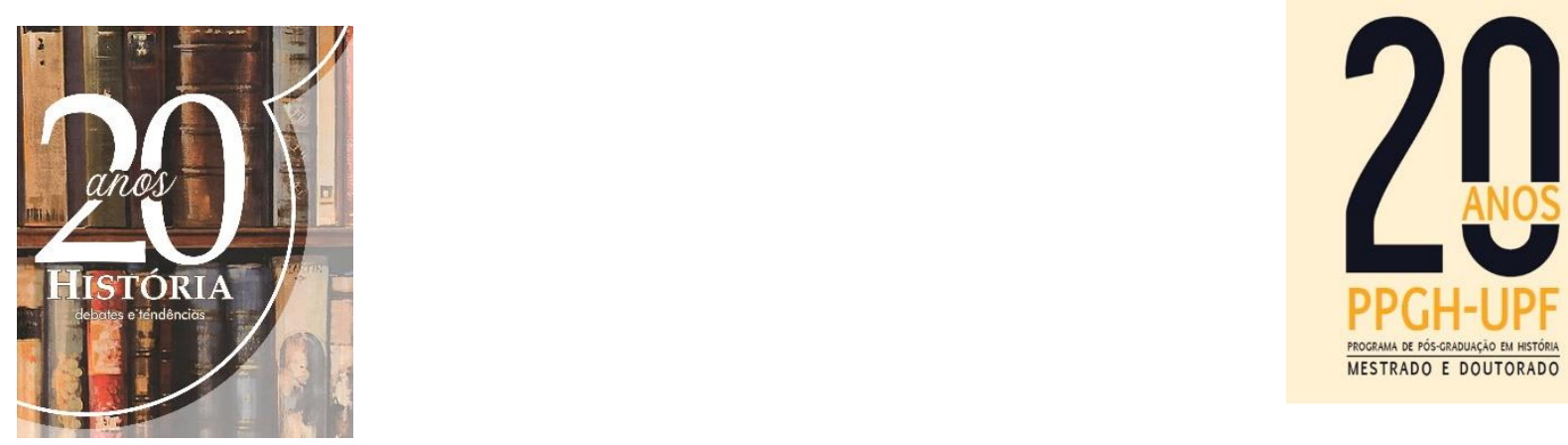

\title{
Textos de fundação: a constituição narrativa da Guerra contra o Paraguai e a produção do patrimônio moral da Nação.
}

\section{Foundation texts: the narrative constitution of the War against Paraguay and the production of the nation's moral heritage.}

\section{Textos fundamentales: la constitución narrativa de la Guerra contra Paraguay y la producción del patrimonio moral de la nación.}

Odair Eduardo Geller ${ }^{\mathrm{i}}$

\begin{abstract}
Resumo: Na América Latina, o século XIX foi o do despertar da Consciência Histórica. Através do exercício da escrita literária foram sendo encaminhadas respostas para questões essenciais, tais como a da essência individualizadora dos povos, do perfil das novas nacionalidades, de suas identidades através do tempo. Nesse aspecto, a confecção de Histórias Nacionais perseguiu no plano ideológico, o efeito de unidade que a duras penas os Estados buscavam lograr no plano político. Exemplo são os trabalhos de José Bernardino Bormann, Juan Crisóstomo Centurión e José Ignácio Garmendia, homens de armas que depois de terem tomado parte no conflito, o constituíram por escrito, utilizando-se largamente de referências clássicas e românticas. No horizonte, a necessidade de promover a aquisição de um patrimônio moral para a Nação.
\end{abstract}

Palavras-chave: Classicismo-romantismo. Escrita da História. Identidade nacional.

Abstract: In Latin America, the nineteenth century was the dawn of historical consciousness. Through the exercise of literary writing, answers were sent to essential questions, such as the individualizing essence of peoples, the profile of new nationalities, their identities over time. In this respect, the making of National Stories pursued ideologically, the effect of unity that the states struggled to achieve politically. Examples are the works of José Bernardino Bormann, Juan Crisóstomo Centurión and José Ignácio Garmendia, men-at-arms who, after taking part in the conflict, constituted it in writing, using largely classical and romantic references. On the horizon, the need to promote the acquisition of moral heritage for the nation. Keywords: Classicism-Romanticism. History Writing. National identity.

Resumen: En América Latina, el siglo XIX fue el amanecer de la conciencia histórica. Mediante el ejercicio de la escritura literaria, se enviaron respuestas a preguntas esenciales, como la esencia individualizadora de los pueblos, el perfil de las nuevas nacionalidades, sus identidades a lo largo del tiempo. En este sentido, la realización de Historias Nacionales persiguió ideológicamente, el efecto de la unidad que los estados lucharon por lograr políticamente. Ejemplos son las obras de José Bernardino Bormann, Juan Crisóstomo Centurión y José Ignácio Garmendia, hombres de armas que, después de participar en el 
conflicto, lo constituyeron por escrito, utilizando referencias en gran parte clásicas y románticas. En el horizonte, la necesidad de promover la adquisición del patrimonio moral para la nación.

Palabras clave: Clasicismo-romanticismo. Escritura de historia. Identidad nacional.

\section{Um Panorama do Estado das Letras na América Latina do Século XIX}

A cultura literária da América Ibérica se constituiu pela acomodação de diversas camadas de influência, em um processo iniciada no período colonial. Com a independência política e a consolidação da abertura das fronteiras geográficas para o mundo, houve um aumento significativo na circulação de ideias. Acompanhadas das impressões causadas pelos acontecimentos que sacudiram o Velho Mundo no século XIX, os ideais modernos foram esvaziados em um processo de apropriação reticente, realizado por uma elite ainda agarrada a instituições coloniais.

Se o linguajar e o universo das representações revelavam a matriz humanista, a influência da Ilustração ensimesmou o olhar latinoamericano, levando a descoberta da fauna e da flora do continente. Segundo Leopold Zea:

Armado do método da nova ciência, o experimental, a flora e a fauna, a terra e o céu americanos, foram objetos de conhecimento. Pouco tempo levou para que se dessem conta, [...]. A América tinha sua personalidade; era possuidora de uma rica individualidade em todos os seus campos (1974).

Nesse sentido, muitas foram as ideias apropriadas por latino americanos imbuídos da tarefa de dar nome ao subcontinente, reivindicá-lo. Exemplo desta atitude foi a forma adquirida pelo romantismo, que, atribuindo uma importância maior a história e a cultura, as temáticas locais e regionais, enriquecidas com relatos sobre a realidade das populações, embebido de "calor sentimental", constituiu uma generosa fonte de referências para a causa emancipacionista. Determinado o tom da abordagem, a demanda nacionalista constituída como Projeto de Futuro, agregou as temáticas de recorte geográfico, outras de ordem mais geral, como a da fundação de "uma cultura, uma literatura, uma gramática, uma filosofia" e uma História, genuínas. No caso desta última, a "partir da influência de Herder e Hegel, de seus interpretes franceses, Cousin e Leroux", a História foi alçada à condição de ferramenta adequada a constituição do Espírito dos Povos (ZEA, 1974). ${ }^{\text {ii }}$

Representante do pensamento latino-americano no período, o trabalho do venezuelano Andrés Bello ilustra a fórmula que orientou a produção literária de grande parte do primeiro século de independência no continente. Radicado no Chile, responsável pela fundação e 
estruturação da Universidade no país, Bello produziu uma vasta obra relacionada a Epistemologia da História. Por ela, defendeu a prioridade do estudo dos fatos locais, a fim de "ver as coisas como foram, os contextos de possibilidades que as viabilizaram", para ao final, apresentar a juventude o "organismo vivo do homem social”. (BELLO apud AMUNATÉGUI, 1882). Para chegar à "filosofia da história de um grupo", ao "espírito peculiar da raça, do povo, da época", seria necessário estudar os seus feitos, "individualizados, vivos, completos", em uma atitude indutiva:

Estamos cansados de ver a história transformada em uma sofista dócil e assalariada que oferece tudo o que dela se exige. O que se pede são acontecimentos em seus detalhes, em seu movimento, neste grande drama do qual somos atores e testemunhos. É assim que se pode conhecer a existência dos povos e dos indivíduos. Se exige que a história os evoque, os ressuscite a nossa vista (BELLO, 2003).

Para revelar os resultados das pesquisas, Andrés Bello propôs o modelo narrativo, através da qual seria possível dar "vida histórica as massas de homens e aos personagens individuais", outorgando um necessário colorido aos textos: "o método mais eficaz é o narrativo, pois combina a sujeição aos acontecimentos e a incorporação de um ritmo que integra o tempo da história ao presente do leitor, tornando o texto mais vívido”. (BELLO apud ALVARADO, 2011). Com a narração seria possível aproximar a obra do leitor, provocando a "persuasão através de um sentimento vivo e profundo", em um ritmo que "vem do passado e vai ao futuro", se prolongando no leitor, "fazendo do texto histórico um espaço dialógico vital". Mais do que narrar, Bello "conta, pondo as nossas vistas as cenas e os personagens. Elos ai! Nosso espírito pode recolher e se apropriar de impressões profundas, de reflexões sob a forma de imagens vivas"(2011).

Em Andrés Bello, a grande quantidade e densidade dos acontecimentos que marcaram o século XIX, contribuíram para a constituição de um ambiente propício ao "restabelecimento do antigo prestígio da narração" e ao retorno dos grandes "pintores". (2003). Este talento havia sido verificado nos historiadores gregos e romanos, que o "fizeram como o fim ou o meio de suas composições, as apresentando com uma ingenuidade candorosa, com a inspiração de um sentimento vivo e profundo". (BELLO apud ALVARADO, 2011)

Qualquer estudo que se proponha a abordar obras que nominalmente trataram de História na América Latina do século XIX, deve prescindir da tentação de classifica-las de antemão. Em Facundo, de Domingo Faustino Sarmiento, por exemplo, se podem perceber traços de formas como a "novela, a história, o poema épico e o ensaio sociológico". A 
preocupação do argentino, bem como dos demais escritores no período, foi a do “convencimento do leitor", de sedução para as questões de interesse da Nação. (ALVARADO, 2011). Ao lado do estilo narrativo, completam a estrutura textual, o tom épico e a forma trágica, que apela para sentimentos universais, como o a dor e o sofrimento. No caso deste, há uma função pedagógica, uma vez que através dos personagens que sofrem são revelados os valores e o caráter de um horizonte nacional. Ao ascenderem à imortalidade, indivíduos e episódios constituídos textualmente se tornam a fonte em direção a qual as gerações seguintes são conduzidas para serem providas de energia vital:

Fenômenos tais como o amor, o envelhecimento, doenças, o medo da própria morte e o sofrimento pela morte de outros, a brevidade e a fragilidade da existência humana, o contraste entre a fragilidade da humanidade e a aparente eternidade do cosmos, são traços recorrentes das culturas humanas, não importa de quantas maneiras diferentes eles possam ser representados (EAGLETON, 2012).

Essas referências não constituem uma reação "a-histórica", como lembra Terry Eagleton, pelo contrário, "a história humana inclui a história do corpo, que com relação ao sofrimento físico, mudou muito pouco no decorrer dos séculos”. (2012). Dessa forma, histórias e vidas datadas em períodos distintos, mesmo que não partilhem de qualquer objeto material comum, podem se aproximar através da linguagem do sofrimento. As tragédias e os épicos, como histórias com finais infelizes e enternecedores, memoráveis mesmo, se tornam edificantes pela sua capacidade de promover aproximação através da partilha de emoções universais.

Estas narrativas constituem o que Manuel Salgado Guimarães chamou de "textos de fundação", uma "forma peculiar de escrita, a escrita da história do ponto de vista nacional" e, também, "da emergência do historiador no mundo das letras". Esforço de constituição de uma História para a Nação, ao narrar "a sensibilidade e a intuição alimentaram a construção de representações que incorporaram, em maior ou menor grau, a imaginação”. Guiando estas ações, a preocupação em assegurar,

[...] um lugar na história universal para o Brasil (Argentina, Paraguai, ...), ou seja, um lugar no concerto das nações civilizadas. Não é desconhecida, da parte de Pedro II e daqueles que o cercavam no IHGB (e os demais Institutos), a preocupação com a memória que deixariam para o futuro, ou seja, a preocupação com a construção e gestão de uma memória coletiva (2010).

Partindo da hipótese de que a oficina do historiador latinoamericano do final do século XIX era provida das mesmas ferramentas, ou então, de uma utensilagem muito próxima, proponho uma breve reflexão sobre o horizonte intelectual no Brasil, na Argentina e no Paraguai. Para viabilizar o estudo, seleciono um acontecimento, talvez o maior acontecimento 
daquele século, a Guerra contra o Paraguai, e a partir dela, três historiadores: o brasileiro José Bernardino Bormann, o argentino José Ignácio Garmendia e o Paraguaio Juan Crisóstomo Centurión. Neles, a constatação da partilha de questões comuns: o tema da Guerra, da qual participaram como soldados e, mais tarde, historiadores; o período em que escrevem, as últimas décadas do século XIX; a Questão Nacional; o contexto institucional de vinculação com o Estado; a significativa reincidência e o exemplo dos autores e figuras clássicas, especialmente gregas.

\section{A Argentina de José Ignácio Garmendia}

Os intelectuais que dariam forma a cultura Argentina após o período de Juan Manuel Rosas, constituíram grande parte do seu repertório teórico no exílio. Com ascensão de Bartolomeu Mitre, em 1860, e o regresso de grande parte dos desterrados, se inicia um período de Reorganização nacional, que alcançou o seu ponto alto com a presidência de Júlio José Roca, em 1880. Nesta fase se constituem as instituições culturais e se difunde a vida intelectual, inaugurando a fase moderna da História da Argentina.

Com Roca, a imigração europeia e o crescimento da vida urbana trouxeram novos atores sociais, os filhos de imigrantes e das classes médias urbanas, homens que representaram uma fase de progressiva profissionalização da atividade intelectual. Apesar da significativa renovação, os principais nomes do campo intelectual do final de século ainda estavam vinculados a aristocracia criolla tradicional. Ocupando cargos na administração pública, estes intelectuais aristocratas, desenvolveram um pensamento caracterizado pela presença de referenciais positivistas, da cultura científica e do romantismo nacionalista. Entre os nomes capazes de ilustrar o perfil destes senhores, para os quais a vida política e o exercício das letras se confundiam, figura Miguel Cané:

Filho de pai exilado durante a ditadura rosista, estudos no Colégio Nacional, bacharel em direito pela Universidade de Buenos Aires, jornalista em Diários portenhos de prestígio, deputado, diretor dos correios e telégrafos, ministro, senador, diplomata, redator da lei de residência, e como final digno, enterro no cemitério da Recoleta. [...]. Estavam ligados pelo sangue, a história e a vida rotineira que levavam. Os mesmos cavalheiros que de manhã interrompiam os seus sonhos, durante o Te Deum, sentados em suas selas de felpas vermelhas, postos em duas filas, frente a frente, ao longo da nave principal da catedral e que se saudavam cerimoniosamente quando suas carruagens se cruzavam a tarde, em Palermo, essa mesma noite ceavam e bebiam juntos no Jockey Club e continuavam suas discussões na manhã seguinte nos salões de um dos seus outros clubes: o Congresso Nacional e a Bolsa de Valores (BRUNO, 2012). 
José Ignácio Garmendia é um represente do grupo que Mc GANN chamou de “gentlemans escritores". (1965). Nascido em uma família de posses, na primeira metade do século XIX, frequentou as melhores e mais tradicionais escolas de Tucumán e Buenos Aires. Sua formação intelectual, no entanto, foi complementada com a vivência do exílio no governo Rosas, na carreira diplomática e, como homem do seu tempo, na absorção do nacionalismo característico do primeiro século de independência.

Leitor compulsivo, José Ignácio Garmendia acumulou um considerável acervo bibliográfico, composto de obras na área das técnicas militares, e principalmente, de títulos associados a História Militar. iii Este último segmento, talvez ajude a explicar a considerável quantidade de referências a episódios da História clássica presentes nos seus volumes sobre a Guerra contra o Paraguai. Expediente que pode ser verificado também no paraguaio Juan Crisóstomo Centurión e no brasileiro José Bernardino Bormann, as citações de heróis e acontecimentos presentes nessa literatura, constituem uma estratégia que procura emprestar ao conflito sul americano a dimensão de grandeza épica do legado greco-romano.

Já no primeiro volume dos Recuerdos de la Guerra del Paraguay, ao descrever a forma através da qual Francisco Solano López dispôs suas tropas em Tuyuti (24/05/1866), a envergadura da obra de construção das suas linhas de defesa, Garmendia os compara aos campos de guerra romanos. Nesse sentido, escreve:

[...] apesar de sua inaptidão para tomar a ofensiva ou levar a adiante a mais simples operação de guerra, (em Tuyuti López) escolheu de forma inteligente as suas posições. [...]. Elegeu suas posições em um solo desigual para construir suas formidáveis linhas, que nos recordam sempre as colossais obras dos campos romanos (GARMENDIA, 1889).

Ainda em Tuyuti, López dá lugar a "Anteo", gigante da mitologia grega, descrito como "pedante e orgulhoso":

Aquela imaginação exaltada, atormentada pelos contrastes do seu imenso orgulho, era como Anteo: buscava forças no infortúnio, e apesar de sua falta de valor físico, tinha um grande caráter moral que se manifestou inquebrantável até o último momento; tenacidade calculada, que sacrificando seu bem-estar pessoal, a colocou a serviço do seu bárbaro poder (GARMENDIA, 1889).

Para apresentar aos leitores a Batalha de Sauce, o historiador argentino elabora uma extensa ekphrasis. ${ }^{\text {iv }}$ Demonstrando o total domínio da técnica, a narrativa faz o leitor ver o encontro dos exércitos acontecendo a frente dos seus olhos. Ao final, a referência a Homero confirma o caráter épico do embate: "No conjunto a visão daquele campo feria a vista, contrastando variados uniformes ensanguentados, que davam ao quadro um aspecto de 
entrevero homérico, que cessava apenas para recomeçar com novo ardor" (GARMENDIA, 1889).

Em meio a constituição narrativa da Batalha, Garmendia faz uma pausa, atraindo o olhar do expectador para o comportamento de um soldado compatriota, aqui, a representação ontológica do ser argentino. É o "Capitão Molina”, que aparece desafiando a morte como um "estoico":

Uma granada de 68 levanta um monte de terra que, dando contra o corpo do capitão Molina, o lança a uma certa distância: quando todos o imaginavam morto, surge o capitão do $2^{\circ}$ Batalhão, lançando um olhar sarcástico, em que demonstrou sua calma estoica, e se põem novamente a frente de sua companhia, a animando com mais brio. (1889).

Ao iniciar a seção dedicada a narrar a Batalha de Curupaytí, a grande derrota aliada no conflito, o historiador argentino alimenta o espírito do leitor com a trágica evocação da memória dos que pereceram neste combate. A partir de Homero, declara:

\begin{abstract}
Aquela perspectiva sangrenta, triste reminiscência das vossas façanhas, cresce naquele grandioso quadro hoje tomado pela tristeza da morte, sublime pelo valor, brilhante pelo movimento homérico da batalha, fúnebre pelas amargas recordações da tumba, que naquela atmosfera transparente, vibram no sussurro das brisas como o dolorido murmúrio de uma grande desventura. (GARMENDIA, 1889).
\end{abstract}

Há pouco mais de duas décadas da batalha de 22 de setembro de 1866, nos Recuerdos, os mortos fisicamente ressurgem aos olhos dos vivos, seus devedores. Falando sobre o local do enfrentamento bélico, escreve: "hoje sois um lúgubre silêncio e os viajantes que pisam indiferentes o palco da luta, não sentirão nele o epitáfio imortal do herói grego [...]”. $\mathrm{Na}$ narrativa, o soldado argentino, como os personagens do gênero clássico exalam grandeza e imponência: "os granadeiros de postura valente e estatura hercúlea marcham a frente do batalhão e seu passo firme imprime a cena uma atitude de vitória que anima até os mais tímidos" (GARMENDIA, 1889).

Assim como o Capitão Molina, em Yataity (1866) os soldados argentinos desdenham a morte: "ao ritmo do canhão dos seus contendores, que iam outorgando ao ambiente uma lúgubre cadencia, os solados respondiam com ciclópicas risadas, ironizando os esforços dos seus contendores". No mesmo segmento narrativo, conclui que "todos estiveram ali ansiosos para buscar a glória, oferecendo com nobre abnegação a tinta vermelha para escrever essa página que na epopeia da história se chama Curupaytí!"'(GARMENDIA, 1889).

A constituição por escrito realizada por José Ignácio Garmendia representa a reinvindicação de valor moral para o comportamento do soldado argentino, material para a 
composição do imaginário nacional das futuras gerações. Na escolha das formas épica e trágica, está contida a consciência do caráter sensibilizador de emoções universais como a dor, o medo e a morte. A ekphrasis do revés que um batalhão argentino sofreu em Sauce, é ilustrativa da forma do uso das categorias:

Um silêncio de morte e a melancolia gerada pela derrota dominavam aquele grupo taciturno: os uniformes despedaçados e ensanguentados; os rostos sombrios, sem vida, enegrecidos pela poeira, pela pólvora e o suor que deslizava em escuros sulcos, mesclados a gotas de sangue; o cansaço revelado por um passo pesado e indiferente, imprimindo uma postura imperturbável naqueles homens de bronze; o sentimento de dor nivelando as patentes; os tons sombrios da silenciosa paisagem revelando a beleza da criação naquele desfiladeiro fatal, sombreado por altas e escuras árvores que espalhavam pelas frestas de suas folhagens, caprichosas manchas de sol movendo inquietas na ardente arena ensanguentada; o som distante, quase imperceptível, dos gemidos dos feridos, abandonados naquele terrível cenário, conduzidos por uma brisa suave, indiferente como a dor indescritível da mais horrível das separações; tudo, todo esse conjunto, harmonioso em seus dolorosos detalhes, constituía o trágico fim do primeiro ato de uma epopeia imortal (GARMENDIA, 1889).

Politicamente liberal e nacionalista, a literatura de José Ignácio Garmendia é romântica ao estilo latino-americano do final do século XIX. Para além de um exercício de historiografia, os seus Recuerdos de la Guerra del Paraguay foram constituídos por escrito para se tornarem uma aquisição para sempre, uma base de sustentação do ethos nacional.

\section{O Paraguai de Juan Crisóstomo Centurión}

Para José Vicente Peiró é a partir do governo de Carlos Antônio López (1842-1862), que a vida cultural ganha alguma expressão no Paraguai. O principal indício da atividade intelectual neste período, teria sido a fundação da "Revista La Aurora", em outubro de 1860, o ponto de partida do romantismo no país. Nas páginas do periódico, Peiró vê os "primeiros testemunhos literários do Paraguai independente" (2000).

Responsável pela criação da "La Aurora", o espanhol Idelfonso Bermejo esteve à frente das principais iniciativas culturais da segunda metade do governo de Carlos López. Recrutado na França por Francisco Solano López, filho e futuro sucessor, Bermejo instituiu o ensino superior no país, através de suas Aulas de Filosofia. Sobre a sua estrutura e funcionamento, Centurión escreve:

Nas aulas de filosofia o Sr. Bermejo desenvolveu um verdadeiro plano de estudos, cujo programa compreendia as seguintes matérias: Gramática castelhana, lógica, História sagrada y profana, Cosmografia, Geometria, Literatura, Moral e Teodiceia, Catecismo político, Direito Civil, Francês e composições literárias (CENTURIÓN, 1995). 
Em função do seu desempenho nas Aulas, Centurión foi contemplado com uma bolsa de estudos na Europa. Na Inglaterra, onde foi estudar direito, Shakespeare lhe impressionou intensamente, o definindo como "o pintor mais fiel da verdade que a humanidade possuiu", dono de um "estilo poético que é como uma chama que arde constantemente sem decair, desde o princípio até o fim, alimentada pela profundidade inesgotável de sua rica e poderosa imaginação". (CENTURIÓN, 1995). Anos mais tarde, ao constituir por escrito os quatro volumes de suas Reminiscencias históricas, o paraguaio revelou a mesma capacidade de envolver, fazendo crer que as sensações provocadas pelo ilustre inglês foram levadas para a sua vida intelectual.

Além do ilustre inglês, a obra do historiador de Itauguá também é perpassada pela influência do horizonte clássico. Em todos os volumes das Reminiscências se fazem presentes heróis e episódios da literatura greco-romana, em uma estratégia que se repete, auferir grandeza épica ao episódio sul americano. Em Mocedades, uma autobiografia, Centurión classifica Homero como aquele que marcha "a frente de todos os gênios", com sua "lira triunfando sobre os estragos do tempo". (1995). No primeiro volume das Reminiscências, antes de iniciar a constituição narrativa do conflito propriamente dito, lembra da morte do pai, afirmando que "as barcas romperam o fio da sua vida". (CENTURIÓN, 1897a). Mais a frente, ao registrar a fundação do primeiro teatro de Assunção, atribui a consecução da obra a inspiração de "Melpômene", a "musa da tragédia" grega. Ainda no âmbito do espaço autobiográfico, registra um sonho que teria acontecido as vésperas do embarque em direção a Europa, para ele um um sinal de que algo novo aconteceria. Para dar sentido a essa sua impressão, cita o bispo grego "Sinésio e os sonhos de Calpurnia, mulher de César e de Olímpia, mãe de Alexandre”. Mais tarde, já a caminho do velho continente, atribui a "Eolos e Netuno" uma tempestade em alto mar. (CENTURIÓN, 1897a).

A constituição narrativa das Batalhas contidas nas Reminiscências históricas aproxima Juan Crisóstomo Centurión de Bormann e Garmendia. Além das referências a personagens e episódios oriundos da literatura greco-romana, o recurso a ekhprasis e a enargeia é recorrente, provendo os episódios de um colorido e uma temperatura que impressionam. Na Batalha Naval do Riachuelo, de 11 de junho de 1865, o tempo é desacelerado pela narrativa, dando ao leitor-expectador a oportunidade de testemunhar o momento em que as águas do rio começam a borbulhar, mudando de cor: 
A água do rio parecia estar fervendo sob o efeito do fogo por conta das inúmeras balas de canhão e fuzil que caiam nele. $\mathrm{O}$ concerto aterrador produzido pelos projéteis ao cruzar o ar, era capaz de impressionar o mais sereno espírito. Que música! Era a do inferno que acompanhava aquela horrenda luta, com uma variedade de cenas dignas de serem descritas por Homero (CENTURIÓN, 1897a).

Noutro episódio, em Corrales (31/01/1866), surgem “poucos paraguaios” para enfrentar com "bravura, firmeza e serenidade", um número infinitamente maior de aliados, num ambiente "comparável as Termópilas". (CENTURIÓN, 1897b). Em Sauce (18/07/1866), a Batalha toma a forma de "um monstro insaciável que tragava carne humana", com os paraguaios que defendiam as trincheiras, agindo como "Hércules" e "Aquiles". $\mathrm{Na}$ mesma sequência, os defensores das trincheiras são comparados aos "troianos" porque resistiram "heroicamente" as investidas da Tríplice Aliança. Graças a essa postura, segundo Centurión, se evitou que já naquele momento, "o objetivo do Tratado Secreto da Tríplice Aliança”, que não era outra coisa que "delenda Cartago", fosse consumado. (CENTURIÓN, 1897b).

Entre os diálogos contidos nas Reminiscências, a entrevista entre Francisco Solano López e Bartolomeu Mitre é significativa, comparada por Centurión a de "Heitor e Ajax na Ilíada”. Em Centurión, López comete o pecado da híbris, quando, entorpecido pela vaidade desafia a ordem estabelecida, arastando todos os paraguaios a uma hecatombe. A partir de Pikicyri (12/1868) no entanto, como em uma peça trágica, a constituição por escrito realizada por Centurión se dedica a redimir o ditador, que depois de purgar os seus pecados, padece imortalizado no "altar de Cerro-Corá". (CENTURIÓN, 1897d).

A marcha em direção ao local onde foi travada a última batalha toma a forma de uma "peregrinação", o "efeito de uma ideia sublime levada ao máximo de intensidade de que é capaz o amor pela terra, o carinho pela casa, pelo ninho onde o calor dessa bela luz que vemos no doce berço, incuba a nossa felicidade e esperança na mais encantadora ilusão do porvenir”. Assim, na "ânsia em cultivar o amor pela pátria" através do exemplo, Lópes cumpre seu destino trágico, tomado por uma sensação "angústia", próxima a "de Ulisses". (CENTURIÓN, 1897d).

Palco do apoteótico encerramento da "epopeia nacional paraguaia", na descrição do historiador, não poderia existir um lugar mais belo, uma paisagem preparada pelas moiras para fechar a "trajetória heroica" dos homens que ainda lutavam:

A luz refletida pelas graníticas e desnudas ladeiras das montanhas de Mbaracayú feridas pelos raios do sol nascente, simboliza o brilho da auréola que circunda o sepulcro onde estão os heróis, que depois de cem duros combates, caíram envoltos na bandeira nacional dando assim ao mundo o mais elevado exemplo de patriotismo [...] (CENTURIÓN, 1897d). 
Cerro-Corá é um monumento de valor moral e patriótico, que elevou Solano López a imortalidade. Assumindo a postura de um aedo, Juan Crisóstomo Centurión proclama que "ao contrário de outros monumentos, que medíocres pelos motivos e no material serão inevitavelmente corroídos pelo tempo, [...], a tumba de Cerro-Corá, como a dos gregos que caíram em Termópilas, viverá de geração em geração até os mais remotos séculos [...]”. (CENTURIÓN, 1897d). Concentrado em povoar o horizonte do imaginário nacional de um país arrasado, não só fisicamente, a morte do ditador, agora redimido, constitui um ato de "imolação":

Cerro-Corá, finalmente, constitui o triunfo moral que alcançou o Paraguai sobre seus inimigos. Basta ler a história da defesa, basta seguir passo a passo o exército nacional para convencer-se de que este não foi derrotado senão totalmente exterminado. Aqueles, na realidade, não conquistaram senão uma tumba! (CENTURIÓN, 1897d).

Se no campo literário Centurión é um romântico, no universo das ideias políticas, ele se revela adepto do evolucionismo e do liberalismo. Entende que a aristocracia da terra tem melhores condições de servir ao Paraguai em função de ter acesso as novidades produzidas no mundo.

\section{José Bernardino Bormann e a História da Guerra do Paraguai}

Na América Latina como um todo, a luta pela independência estabeleceu o tema da Nação como "uma emergência discursiva". Mais do que isso, durante todo o século XIX as ideias de "Pátria, Nação, Estado, ser brasileiro, argentino (ou paraguaio) e americano" permaneceram bastante imprecisas. (MOLINA, 2011). Neste contexto, a literatura foi submetida a um processo de historicização, pelo qual as ideias de origem europeia foram sendo apropriadas como "equipamentos de campanha", instrumentos a serviço do desejo de produzir orientação no tempo. (CANDIDO, 2003). Verdadeiro palimpsesto, o romantismo latino-americano se constituiu na corrente literária de expressão do nacionalismo político.

Em meio a esse ambiente, José Bernardino Bormann iniciou sua formação intelectual estudando com "padres" em São Leopoldo (RS), para depois da Guerra contra o Paraguai, bacharelar-se em Matemática e Ciências Físicas na Escola Militar do Rio de Janeiro, em 1872. 
De acordo com Roberto Acizelo de Souza, a educação de características humanísticas "imperou em todo o ocidente entre os séculos II a.C. e o XIX". No Brasil, os traços linguísticos e literários, somados a retórica e a eloquência, oferecem à "estrutura textual da literatura nacional". (1999). Nesse sentido, "apesar de ter no historicismo o seu modelo orientador, convivendo com este, a produção crítica orientou-se por uma vertente de procedência clássica, que sobrevivendo (e mesclando-se) ao romantismo, prolonga a vigência da retórica e da poética" até fins do século XIX. (1999).

Papel fundamental no desenvolvimento desta identidade pode ser atribuído ao Instituto Histórico e Geográfico Brasileiro (IHGB). Criado em 1838 e adotado pelo Estado Imperial em dezembro de 1849, os seus membros receberam a incumbência de produzir as bases históricas para a reivindicação da realidade e legitimidade do Estado-nação. O próprio D. Pedro II, em discurso na cerimônia de inauguração da sede do IHGB no Paço Imperial, é quem esclarece:

É de mister que não só reunais os trabalhos das gerações passadas, ao que vos tendes dedicado quase que unicamente, como também, pelos vossos próprios, torneis aquela a que pertenço digna realmente dos elogios da posteridade: não dividi, pois, as vossas forças, o amor da ciência é exclusivo, e concorrendo todos unidos para tão nobre, útil, e já difícil empresa, erijamos assim um padrão de glória à civilização da nossa pátria (RIHGB, 1849).

Para Temístocles Cezar, o "plano de historicidade gestado pelo IHGB compreende a uma história magistra vitae promotora de exempla (de modelos) a serem seguidos". (2003). Ele lembra que o objetivo das produções fomentadas em torno do Instituto era o de "criar o exemplo, o exemplar, integrado à retórica da nacionalidade, discurso historiográfico e político extremamente persuasivo desenvolvido ao longo do século XIX, tanto no IHGB como fora dele, tanto na história como na literatura”. (2003). João Manuel Pereira da Silva, um dos membros mais atuantes do Instituto, assim sintetiza a tarefa do escritor:

A descrição e a moralização, a pintura e o juízo, a narração e o raciocínio, são os elementos indispensáveis para traçar-se o grande quadro dos acontecimentos humanos, indagar-lhes as causas, descobrir-lhes os resultados, ligar a vida do indivíduo à vida da sociedade, reunir o homem à espécie, e formar assim a grande lição para que foi instituída a história. Verdade e compreensão, justiça e inteligência, sabedoria e imaginação, é lhe tudo necessário para dar vida à sua história, alma à sua narração, interesse à sua obra, fisionomia peculiar às épocas que descreve, e vestes próprias aos acontecimentos que narra (SILVA apud CEZAR, 2003).

Em 1897 José Bernardino Bormann é indicado como membro correspondente do IHGB. Na apresentação de Dias Fratricidas, obra publicada em 1901, ele define o exercício da História como essa aquisição para sempre: "a missão sublime de mostrar aos homens os erros, para evitar a sua reprodução no presente e no futuro". (BORMANN, 1901). " Na dedicatória do 
primeiro volume da sua História da Guerra do Paraguai, Bormann já havia definido o recurso a escrita da História dos fatos recentes como um antídoto contra a injustiça.

Na sessão de 6 de outubro de 1914, Viveiros de Castro, comparou José Bernardino Bormann com "Xenofonte e a Taunay", todos "militares que ilustram a história pátria, antes de (como historiadores) escrever as suas páginas imortais". Na mesma manifestação, as obras do veterano da Guerra contra o Paraguai, foram caracterizadas como "bem documentadas" e capazes de serem "lidas com prazer". (RIHGB, 1916). Tristão de Alencar Araripe destaca o estilo de José Bernardino Bormann, afirmando que as cenas narradas revelam que mesmo em obras "atulhadas de datas e nomes", existem "clareiras" que podem ser ocupadas pelo historiador para revelar a colaboração da "poesia com a erudição". (1950). Para Cezar, essa seria uma das noções fundamentais da cultura histórica brasileira do século XIX, caracterizada pela presença de:

[...] certas diretrizes capazes de tornar mais atrativa a leitura da história da nação ao expor fontes áridas ou herméticas, porém conservando sua dimensão criativa. A despeito de seu evidente valor poético, de seu constante apelo à imaginação, de uma perspectiva onde o prazer estético não é desprezível, a aplicação dos princípios da cor local funciona como uma das premissas da organização narrativa, pois os historiadores da nação têm necessidade de cativar seus leitores com uma história que seja verdadeira e agradável de se ler. (2003).

No seu discurso de posse, José Bernardino Bormann exaltou Schiller, lhe atribuindo o renascimento do gosto pela História na Alemanha: "Schiller fez reviver, em toda a Alemanha, o gosto pela história. Depois dele, logo apareceram muitas memórias, biografias, anais, monografias e crônicas que como materiais de consulta, oferecem informações que dão a chave de certos enigmas obscuros da história". Com Schiller, os grandes homens encontraram na história "modelos dignos de imitação". (RIHGB, 1916).

Na sua constituição por escrito da História da Guerra contra o Paraguai, assim como em Garmendia e Centurión, a referência ao horizonte dos autores e personagens clássicos é farta. Entre mais uma dezena de episódios classificados como capítulos de uma "epopeia", está a Batalha naval do Riachuelo (11/06/1865). Em Bormann, trata-se de um "capitulo da nossa Ilíada", o dia de uma "epopeia grandiosa", nos moldes de Homero:

Afinal, ao despedir-se o dia que tinha iluminado por tanto tempo o cenário em que se exibira aquela epopeia grandiosa de sangue, de ações heroicas, extraordinárias e maravilhosas; em que os nossos marujos e soldados escreveram uma das páginas mais sublimes da nossa ilíada; os canhões de Bruguez (paraguaios) ficaram mudos e frios, concentrados certamente na dor e angustia da tremenda catástrofe nacional. (BORMANN, 1897a). 
Em outro momento, tratando da invasão paraguaia ao Mato Grosso, o historiador compara os paraguaios aos bárbaros germânicos. Desqualificando o invasor, procura oferecer ao leitor condições de visualizar a presença e a ação do inimigo, que tal como na antiga Roma, deixa um rastro de destruição por onde passa:

A guerra, que nos faz o inimigo, lembra a invasão dos bárbaros: é a guerra de extermínio; é a morte com a desonra, o saque e o incêndio, sem, entretanto, aqueles lampejos de generosidade que, ás vezes, honravam as hostes dos hunos ou as tiufadias dos godos. A presença de um inimigo que tudo devasta, infunde intenso terror: as populações fogem como na Espanha, quando os sarracenos, espalhando a morte e a ruína em seu solo, levavam tudo de vencida e arrancavam do peito dos fugitivos aquele grito angustioso: — os Árabes!As nossas populações, embrenham-se pelas selvas, e, transidas de horror, têm uma só exclamação: — os Paraguaios! (BORMANN, 1897a).

Depois de narrar a Batalha de Tuyuti (24/05/1866), Bormann busca no romano Otávio Augusto, o meio para ilustrar o estado de espírito do derrotado López: "Ele podia, com alguma razão, exclamar depois dessa batalha, como Augusto, ao saber da destruição do seu exército pelo terrível Arminius, nas florestas de Teutberg: Varrus, Varrus! Restitui as minhas legiões! ”. (BORMANN, 1897a). ${ }^{\text {vi }} \mathrm{Na}$ mesma sequência, trata da reconhecida valentia dos paraguaios em campo de batalha. Para explicá-la, o historiador faz referência as penates romanas:

Os paraguaios eram valentes porque descendiam dos guaranis e porque aprendiam com a Igreja sobre a ressurreição. Estas ideias de ressurreição, ali também incutidas pelos Jesuítas, e chefes militares, eram mantidas pelo clero nacional, e assim, além do valor inato da raça, esse valor tomava proporções enormes, porque a morte no campo de batalha não era mais do que o rápido regresso aos penates. (BORMANN, 1897a).

Em Bormann, assim como em Centurión e Garmendia, a atitude da comparação e da referência foram, para concluir, utilizadas para fazer ver e convencer o leitor-expectador da verdade que buscavam transmitir.

\section{As referências como chave de leitura}

José Ignácio Garmendia, Juan Crisóstomo Centurión e José Bernardino Bormann pertencem aos quadros do romantismo latino-americano de fins século XIX. Se referindo ao brasileiro, Walter Spalding escreve:

Sua obra, ainda que escrita em um estilo mais ou menos pesado, é sem dúvida muito significativa pelas suas conclusões, sua documentação e as observações que contém. Bormann pertence ao pequeno grupo dos grandes historiadores daquelas épocas agitadas da vida no Brasil (e na América Latina). (1947). 
Chamados a colaborar na constituição de um horizonte de referências éticas e morais capazes de sustentar ontologias nacionais, eles foram arrastados a Guerra, para anos mais tarde eleva-la a condição de acontecimento central do Volksgeist nacional. O trabalho de constituição escrita do grande acontecimento se deu em meio a uma oficina rica em ferramentas, as mais variadas, caso das formas épico-dramáticas e do recurso a expedientes retóricos, o caso da ekphrasis e da enargeia.

Escrevendo para populações carentes de orientação, em um período de tumultuadas transformações, é possível considerar que o trio teve no grego Tucídides, e na sua História da Guerra do Peloponeso, uma referência comum. (TUCÍDIDES, 2013). Além dos expedientes presentes na oficina do Ateniense, a constante citação de autores, personagens e expressões clássicas, constituem parte de um esforço que, em última instancia, visou transferir grandeza épica ao conflito. A Guerra contra o Paraguai não foi inventada pela literatura, mas sem dúvida, suas potencialidades dramáticas e emocionais foram exploradas por homens de letras interessados em promover uma "aquisição para sempre". Assim, no exercício da literatura, e especialmente, na constituição narrativa da Guerra, realizada pelos três historiadores, podemos ver um esforço de constituição de textos fundacionais, referências de valor que se apresentam como fontes de exemplo e compromisso para as futuras gerações.

\section{Referências}

ALVARADO, L. Bello y Sarmiento: dos modos de estudiar la historia. Hipertexto, Massey University, n.13, p. 120-131, 2011.

AmunAtÉGui, M. L. Vida de Don Andrés Bello. Santiago de Chile: Pedro G. Ramirez, 1882.

ARARIPE, T. de A. Paraná: remanso de glórias. Curitiba: 1950, mimeo

BELLO, A. Modo de escribir la historia. Biblioteca Virtual Universal, 2003. mimeo.

BORMANN, J. B. Dias fratricidas: memórias da Revolução Federalista no Estado do Paraná. Curitiba: Typ. da Livraria Econômica de Anibal Rocha e CIA, 1901,

vol. I.

. História da Guerra do Paraguai. Curitiba: Impressora Paranaense, 1897,

BRAGA, C. M. Melodrama: as estratégias trágicas da emoção na modernidade. Disponível em: https://www.publionline.iar.unicamp.br/index.php/abrace/article/view/1270. Acesso em 20/nov./2019. 
BRUNO, P. Vida intelectual de la Argentina de fines del siglo XIX y comienzos del XX: um balance historiográfico. PolHis, Mar del Plata (AR.), ano 5, n. 9, p.69-91, jan./jul., 2012.

. La vida letrada porteña entre 1860 y el fin-de-siglo: coordenadas para un mapa de la elite intelectual. Anuario IEHS, Tandil (AR.), n. 24, p.339-368, 2009.

CENTURIÓN, J. C. Mocedades: los sucesos de "Puerto Pacheco". Bahía Negra (PY): Instituto Colorado de Cultura, 1995.

. Reminiscências históricas sobre lá Guerra del Paraguay. Vol. 4. Assunción: Imprenta Militar, 1901.

. Reminiscências históricas sobre lá Guerra del Paraguay. Vol. 2. Buenos

Aires: Imprenta de obras de J. A. Berra, 1894.

. Reminiscências históricas sobre lá Guerra del Paraguay. Vol. 1. Buenos

Aires: Imprenta de obras de J. A. Berra, 1894.

CANDIDO, A. A Literatura Durante o Império. In: HOLANDA, S. B. (Org.). História Geral da Civilização Brasileira. RJ: DIFEL, T. II, V. 3, 2003.

CEZAR, T. Livros de Plutarco: biografia e escrita da história no Brasil do século XIX. MÉTIS: história e cultura. v. 2, n. 3, p. 73-94, jan./jun. 2003.

EAGLETON, T. Doce violência: a ideia do trágico. São Paulo: UNESP, 2012.

GARMENDIA, J. I. Recuerdos de la Guerra del Paraguay. Vol. 1, 3ª ed., Buenos Aires: Casa editora de Jacob Peuser, 1889.

GONZÁLEZ-STEPHAN, B. Fundaciones: canon, historia y cultura nacional. La historiografía literaria del liberalismo hispanoamericano del siglo XIX. Madrid: Iberoamericana, 1987.

GUIMARÃES, M. L. S. Livro de fontes de historiografia brasileira. Rio de Janeiro: EdUERJ; FAPERJ, 2010.

MOLINA, D. A. A historiografia literária na Argentina e no Brasil: romantismo(s) e nacionalismo. Dissertação (Mestrado) - Universidade de São Paulo, Faculdade de Filosofia, Letras e Ciências Humanas, São Paulo, 2011.

MC GANN, T. Argentina, Estados Unidos y El Sistema Interamericano (1880-914). Buenos Aires: Eudeba, 1965.

PEIRÓ, J. V. Manifestaciones literárias del XIX en Paraguay: la revista La Aurora. Revistes Catalanes amb Accés Obert (RACO). Arrabal, n. 2-3. p. 33-40, 2000.

PRIETO, A. El discurso criollista em la formación de la Argentina moderna. Buenos Aires: Editorial Sudamericana, 1988.

GONZÁLEZ-STEPHAN, B. G. A historiografia literaria del liberalismo hispano-americano 
del siglo XIX. Habana, Cuba: Casa de las Américas, 1897.

Revista do RIHGB. Rio de Janeiro. 12 (1916), Out./Dez. 1849.

Revista do RIHGB. Rio de Janeiro, TOMO VI, Vol. 6, Rio de Janeiro, 1844.

SPALDING, W. Historia y Filología, Ensayo y Crítica. Revista UPB, v. 13, n. 48/49, 1947, p. 40-64, Medellín, Colômbia. Disponível em: <https://revistas.upb.edu.co/index.php/ upb/issue/view/321/showToc>. Acesso em: 19/nov./2019.

SOUZA, R. A. de. O império da eloquência: retórica e poética no Brasil oitocentista. Rio de Janeiro: EDUERJ, 1999.

TUCÍDIDES, História da Guerra do Peloponeso. $2^{\text {a }}$ edição, Lisboa: Fundação Calouste Gulbenkian, 2013.

ZEA, L. El Pensamiento Latino Americano. 3. d. México: Editorial Ariel, 1974.

Submetido em: 26/10/2019

Aprovado em: 03/12/2019

Publicado: 23/12/2019

\section{Notas}

' Licenciado em História pela Faculdade de Filosofia, Ciências e Letras de Palmas, PR, FAFI. Mestre em História pela Universidade de Passo Fundo, RS, UPF. Doutor em História pela Universidade Federal do Paraná, UFPR. Email: odair.geller@uffs.edu.br

ii Para facilitar a leitura e outorgar um padrão ao texto, procedi a livre tradução das citações em espanhol.

iii O Arquivo José Ignácio Garmendia está sob a guarda do Archivo de La Nación, sala 7, em Buenos Aires.

iv Oriunda da poesia épica, a ekphrasis se constitui na habilidade de construir cenas e cenários através das palavras, em uma realidade onde o leitor é transportado para dentro dos acontecimentos e lugares, a enargeia. Ver: SOARES, M. T. M. Ekphrasis e Enargeia na historiografia de Tucídides e no pensamento filosófico de Paul Ricoeur. Talia Dixit, ${ }^{\circ}$ 6, 2011, pp. 1 - 23. Disponível em: http://dehesa.unex.es/handle/10662/ 1051?locale-attribute=pt. Acesso em 20/nov. /2019.

v Se o termo "mestra da vida" de Cicero é mais conhecido, a ideia da história como um canteiro de ensinamentos para as gerações vindouras é inaugurada com Tucídides, "Ktema es aei” - aquisição para sempre.

vi No ano 9 da era cristã, três legiões romanas foram massacradas na região noroeste da atual Alemanha pelas forças de líder rebelde "Armínio, príncipe dos Queruscos" e antigo aliado de Roma. Ver: http://dererummundi.blogspot.com.br/2010/02/varo-devolve-as-minhas-legioes.html, Acesso em 19/nov./ 2019. 